\title{
A new disinfectant
}

\author{
PHILIP W. ROSS \\ From the Department of Bacteriology, University of Edinburgh
}

SYNOPSIS Qualitative and quantitative tests have been carried out to assess the value of Cidex ${ }^{1}, a$ glutaraldehyde solution, as a disinfectant.

Most of the tests were qualitative and were carried out in conditions as closely resembling those found in hospital practice as possible. Recently used anaesthetic equipment, catheters, and a cystoscope, which had been artificially contaminated with suspensions of Staph. aureus, Ps. pyocyanea, and Esch. coli, were used in the tests.

The results show Cidex to be a useful disinfectant with a valuable potential in disinfecting $\frac{\omega}{\infty}$ hospital articles which, due to their perishable nature or the fragility of component parts, cannot be 0 treated by physical means.

This paper presents results of several tests done on Cidex, an activated glutaraldehyde solution, to assess its effectiveness as a disinfecting agent. Previous work by Pepper and Chandler (1963) has shown it to have a sporicidal effect and Borick, Dondershine, and Chandler (1964) have published details of work done on its viricidal properties.

These aspects have not been examined in the present study. The purpose here is to assess the ability of this agent to kill organisms which cause the most trouble in hospital cross-infection, notably Staphylococcus aureus, Escherichia coli, and Pseudomonas pyocyanea, under conditions resembling those found in day-to-day hospital practice.

\section{METHODS OF TESTING DISINFECTANTS}

That no single test to date is universally used is proof that no single test is completely satisfactory.

In 1903 Rideal and Walker described their 'phenol coefficient' method. This test is valid only for fluids resembling phenol and is misleading and inaccurate for others. The Chick Martin test has many similar disadvantages.

In 1960 the Association of Official Agricultural Chemists described an example of 'use dilution' tests. Kelsey, Beeby, and Whitehouse (1965), who criticized this on the grounds that the choice of organisms was unrealistic and that it failed to differentiate between disinfectant and detergent properties, recommend a capacity use dilution test. Although suitable only for phenolic disinfectants, it takes into account the presence of organic matter and tests two common pathogens.

\footnotetext{
Cidex is the proprietary name for a preparation of buffered glutaraldehyde marketed by Ethicon Ltd., Edinburgh.

Received for publication 28 April 1966.
}

The present test is simple, easily reproducible, uses $\vec{\bullet}$ pathogens commonly associated with hospital crossinfection, and includes testing the effect of organic matter on the system.

\section{MATERIALS}

The pathogens Ps. pyocyanea, Esch. coli, and Staph. aureus, phage type $80 / 81$, were used.

A cystoscope and four Jaques catheters were tested after being artificially contaminated, and an anaesthetic mask, 31 in. corrugated rubber anaesthetic tubing, and an airway after normal routine use.

The organic material was human blood.

\section{METHODS}

A preliminary test was done to see that the $1 \%$ sodium thiosulphite recommended as an inactivator (Rubbo and $₹$ Gardner, 1965) was not itself bactericidal. It was added in solution to equal volumes of distilled water containing known numbers of organisms $/ \mathrm{ml}$. After contact for periods of two, four, and six hours, six separate amounts of $0.02 \mathrm{ml}$. were removed, dropped on to blood agaro plates and incubated overnight at $37^{\circ} \mathrm{C}$. Bacterial counts $N$ on the following day showed no bactericidal effect by the inactivator.

The first, or basic, part was quantitative to see if Cidex did kill and, if so, at what rate. The second or qualitativeo part was to assess the effect of the disinfectant on contaminated apparatus.

In the first part each organism was diluted in $5 \mathrm{ml}$. 0 distilled water to give an approximate count of $5 \times 10^{5}$ organisms $/ \mathrm{ml}$. Each organism had four tubes with equali़ counts, corresponding to the four different times at which $\frac{}{\mathbb{8}}$ counts were made after contact with the disinfectant. Cidex, $5 \mathrm{ml}$., was added to each separate range of tubes? at the beginning: at five, 10, 15, and 30-minute intervals, $\varnothing$ 
$5 \mathrm{ml}$. sodium thiosulphite was added to each appropriate tube. This was allowed to act for 15 minutes, after which time the tubes were shaken and six separate amounts of $0.02 \mathrm{ml}$. removed, at the specified time intervals.

These six samples for each organism at each time interval were diluted to $1: 100$, dropped on to blood agar plates and incubated overnight at $37^{\circ} \mathrm{C}$. (Table I).

In the second part of the quantitative section the procedures were the same, except that $2.5 \mathrm{ml}$. of blood was added to the suspensions before addition of the disinfectant. In this case the time intervals were 10, 20, and 30 minutes.

In the second part, the qualitative part, the anaesthetic equipment was swabbed and the swabs plated out on blood agar. These articles were then immersed in the disinfectant. At five-minute intervals for 15 minutes they were removed and swabbed (Table II).

The remaining three tests in this section deal with the urinary tract instruments. These articles were placed separately in sterile basins containing $400 \mathrm{ml}$. of distilled water with a count of 600,000 mixed organisms $/ \mathrm{ml}$.

The first test consisted of swabbing these articles at five, 10, 15, and 20 minutes after mere rinsing. In the next part the disinfectant was added at the beginning and swabs were taken from the lumina of the catheters and cystoscope at the same time intervals. The final procedure was the same as the previous one, with the addition of $200 \mathrm{ml}$. blood. The results are set out in Table III.

After overnight incubation on blood agar plates, the plates were read and the growth recorded either as +++ (profuse growth), ++ (moderate growth), + (scanty growth), or - (no growth).

\section{RESULTS}

The question of the choice of an end point in disinfecting experiments causes a division of opinion. There are those who support the total kill end-point and those, such as Withell (1942) and Sykes (1965), who see it as an unnecessary and misleading concept. In the above experiments emphasis was placed on either the number of organisms $/ \mathrm{ml}$. or the quantity of growth remaining after addition of the disinfectant for specified times.

In the two tests done in the quantitative experiments there were no viable organisms found after half an hour of contact with Cidex (Table I). The addition of blood, however, did influence the action

TABLE I

RESULTS OF QUANTITATIVE EXPERIMENTS

Average Organisms/ml. at Stated Times (min.)

\begin{tabular}{ccccccccc}
\hline Cidex Only & & & & \multicolumn{3}{c}{ Cidex and Blood } \\
\cline { 1 - 4 } \cline { 5 - 8 } & 10 & 15 & 30 & & 10 & 20 & 30
\end{tabular}

Staph.

pyogenes $\quad 23,000 \quad 8,000 \quad 1,000$

$\begin{array}{llll}\text { Ps. pyocyanea } & 26,000 & 11,000 & 2,000\end{array}$

$31,000 \quad 11,000 \quad 2,000$

Esch. coli
$22,000 \quad 8,000 \quad 2,000$

$18,000 \quad 11,000-$ of the disinfectant, as some staphylococci and pseudomonads still survived, albeit in small numbers, after half an hour (Table I).

Table II shows the species of organisms found on the used anaesthetic equipment before and after immersion in the disinfectant. Organisms other than the proteus species were removed within five minutes and even with the latter a previously moderate growth became a scanty one. After 10 minutes, however, there was no growth of the proteus organisms.

\section{TABLE II}

SPECIES OF ORGANISM BEFORE AND AFTER IMMERSION Before Immersion

\begin{tabular}{lll}
\multicolumn{2}{l}{ After Immersion } \\
\hline \multicolumn{2}{l}{ Minutes } \\
\hline $5 \quad 10$ & 15
\end{tabular}

\begin{tabular}{cllll}
\hline $\begin{array}{c}\text { Mask } \\
\text { Inside }\end{array}$ & Proteus spp ++ & $\begin{array}{l}\text { Proteus } \\
\text { spp }+\end{array}$ & - & - \\
$\begin{array}{c}\text { Outside } \\
\text { Tubing }\end{array}$ & $\begin{array}{l}\text { (Staph. aureus) }+ \\
\text { (Staph. albus) }+\end{array}$ & - & - & - \\
$\begin{array}{c}\text { Airway } \\
\text { Inside } \\
\text { Outside }\end{array}$ & Staph. albus + & - & - & - \\
& & - & - & - \\
\end{tabular}

As one would expect, mere rinsing of contaminated articles had little or no effect on the bacteria present and profuse growths were obtained from the artificially contaminated catheters and cystoscope (Table III). When Cidex was added to these articles, three of the four swabbed were found to be sterile after 15 minutes and all four after 20

TABLE III

DISINFECTING RATE AFTER RINSING, CIDEX, AND CIDEX PLUS BLOOD

\begin{tabular}{lllll} 
Article & \multicolumn{3}{l}{ Minutes } \\
\cline { 2 - 5 } & 5 & 10 & 15 & 20 \\
\hline
\end{tabular}

Simple rinsing

Catheters

Proximal lumen Distal lumen

Cystoscope

Lumen of sheath Telescope

$\begin{array}{llll}++ & +++ & ++ & ++ \\ ++ & ++ & ++ & ++ \\ & & & \\ +t & +++ & ++ & ++ \\ + & ++ & + & ++\end{array}$

Cidex

Catheters Proximal lumen Distal lumen

Cystoscope Lumen of sheath Telescope

Cidex and Blood Catheters Proximal lumen Distal lumen

Cystoscope Lumen of sheath Telescore 
minutes (Table III). The addition of organic material slowed down the disinfecting rate (Table III), some organisms remaining viable after 20 minutes. The surviving bacteria were all pseudomonads.

\section{DISCUSSION}

In the quantitative tests a satisfactory reduction in the number of organisms was given in a short space of time. The addition of organic material undoubtedly slowed down the process of disinfection due presumably to the coating of the organisms or to the adsorption of the disinfectant by the blood. The latter would also have have a diluting effect on the system.

It was surprising to find proteus organisms inside an anaesthetic mask (Table II) and one wonders, therefore, how much anaesthetic equipment is implicated in respiratory tract cross infection. The finding of some Staph. aureus in the folds of the corrugated tubing, and the fact that the airway contained organisms, in this case coagulasenegative staphylococci only, surely underlines the need for proper disinfection of anaesthetic equipment, a practice which is still far from common at present.

The qualitative tests were considered satisfactory and here again the effect of organic material in slow- ing down the disinfecting rate was seen. This points to the necessity of ridding articles of as much organic material as possible before disinfection. This prim ciple, however, is basic to the use of most disiß fectants.

The disinfectant appeared to have no deleterio effect on the rubber articles and produced corrosion of or damage to the lens system of the cystoscope.

It would appear that Cidex is a valuable addition to the existing armamentarium of disinfectants.

I am grateful to Ethicon Limited for supplies of Cidex and to Mr. Tom Roylance for technical information og the product.

I wish also to thank Dr. B. I. Davies for helpful advitie and assistance in checking the manuscript.

\section{REFERENCES}

Association of Official Agricultural Chemists (1960). Official Methods of Analysis, edited by W. Horwitz, 9th ed. Washington D.C.

Borick, P. M., Dondershine, F. H., and Chandler, V. L. (19\&). J. pharm. Sci., 53, 1283.

Kelsey, J. C., Beeby, M. M. and Whitehouse, C. W. (1965). Mth. Bulh

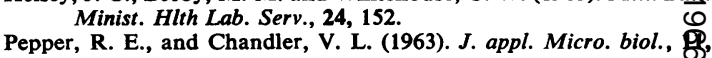
385.

Rideal, S., and Walker, J. T. A. (1903). J. roy. sanit. Inst., 24, 424D

Rubbo, S. D., and Gardner, J. F. (1965). A review of Sterilization aQd Disinfection, p. 130. Lloyd-Luke, London.

Sykes, G. (1965). Disinfection and Sterilization, 2nd ed., p. 61. Spgï, London.

Withell, E. R. (1942). J. Hyg. (Lond.), 42, 339. 